Article

ÖZDEMIR, A. ${ }^{1}$

KOCABAS O. ${ }^{1 *}$

\section{Numerical Comparative Hairs of Some lamiaceae TAXA COLLECTED FROM TURKEY}

\section{Comparação Numérica de Pelos de Alguns Táxons de Lamiaceae Coletadas na} Turquia

\begin{abstract}
In this study, glandular and aglandular hairs were examined and compared numerically in the vegatative and reproductive organs of Salvia viridis, Salvia verticillata subsp. amasiaca, Salvia virgata, Phlomis pungens var. pungen, Phlomis pungens var. hispida, Stachys cretica subsp. anatolica, Stachys cretica subsp. smyrnaea, Teucrium scordium subsp. scordioides. It has been observed that all taxa which are collected Western and Northern Anatolia have glandular hairs and aglandular hairs of various shapes, size and modes of secretion. The hairs variations in eight Lamiaceae taxa were been investigated by means of numerical methods (Analysis of variance and Pearson correlation). It was also found that the results from numerical analysis of the hairs characters can provide additional evidences for the recognition of the taxa.
\end{abstract}

Keywords: Lamiaceae, hairs, numerical.

RESUMO - Neste estudo, pelos glandulares e aglandulares foram examinados e comparados numericamente nos órgãos reprodutivos e vegetativos de Salvia viridis, Salvia verticillata subsp. amasiaca, Salvia virgata, Phlomis pungens var. pungen, Phlomis pungens var. hispida, Stachys cretica subsp. anatolica, Stachys cretica subsp. smyrnaea, Teucrium Scordium subsp. scordioides. Foi observado que todos os táxons recolhidos no oeste e no norte da Anatólia possuem pelos glandulares e pelos aglandulares de vários formatos, tamanhos e modos de secreção. As variações nos pelos de oito táxons de Lamiaceae foram investigadas por meio de métodos numéricos (análise de variância e de correlação de Pearson). Verificou-se também que os resultados da análise numérica das características dos pelos podem fornecer evidências adicionais para o reconhecimento dos táxons.

Palavras-chave: Lamiaceae, pelos, numérico.

\footnotetext{
* Corresponding autor:

<okankocabass@gmail.com>
}

Received: March 26, 2016

Approved: May 05, 2016

Planta Daninha 2017; v35:e017161425

1 Celal Bayar University, Science and Arts Faculty, Muradiye, Manisa, Turkey. 


\section{INTRODUCTION}

The Lamiaceae is a large and natural family composed mostly of herbs and under shrubs containing many useful plant such as sage (Salvia) and mint (Mentha). Lamiaceae is represented by about 258 genera and 3,500 species in the world (Duarte and Lopes, 2007). Turkey is accepted as a gene center for this family (Baser, 1993). With their pleasant fragrance, many species of Lamiaceae have been used as herbal teas in Turkey. Many of the species are used as raw material in the cosmetic industry. Some species are traditionally used as medicinal plants (Baytop, 1984). Dried leaves and flowers of some Salvia species which have effective substance are used for preparing some vegetal drops and in the treatment of some illnesses. Salvia virgata, which is studied in this study, is used as anticeptic and Teucrium scordium, examined here, is used as tonic and stimulant (Baytop, 1984). The source of these features of Lamiaceae species is glandular hair that has etherich oil (Werker et al., 1985). Recent studies on these plant species have shown that the compounds decrease DNA synthesis in the cell. This feature is important in the diagnosis and treatment of cancer (Nakipoglu, 1993). A series of research studies are being conducted to examine the karyological, anatomical, morphological, palynological and phylogeny characteristics of some species belonging to Lamiaceae (Nakipoglu, 1993; Koca, 1996; Özdemir and Senel, 2001; Baran and Özdemir, 2006, 2009, 2011, 2013; Özkan and Özdemir, 2008; Özkan et al., 2009; Baran et al., 2010; Özdemir, 2011; Bendiksby et al., 2011). The purpose of this paper is to determine and numerically compare the hairs of the investigated taxa. Thus, we have focused on finding out the similarities and differences between the taxa.

\section{MATERIALS AND METHODS}

8 taxa belong to Salvia L., Teucrium L., Stachys L., Phlomis L. of the Lamiaceae family were chosen for this study. Plant samples were collected from natural populations between 2014-2015 (Table 1). Anatomical studies were carried out on fresh samples kept in alcohol of $70 \%$, in sartur reactive dye (Baytop, 1981). The cross-sections were used to determine number and type of hair on stem, leaves, petiole, calyx and corolla of the investigated taxa. For the numerical analysis, 9 types of hair were selected and the number of the hairs in the unit area $\left(\mathrm{mm}^{2}\right)$ was used. Hair types were coded as 1-9 and the taxa were coded as A-H. Significance of the differences between the taxa and hair characters were evaluated by analysis of variance (Regression Analysis) and Pearson correlation.

\section{RESULTS AND DISCUSSION}

The eight Lamiaceae taxa were compared numerically by studying hairs on their vegetative and reproductive organs. Glandular and aglandular hairs of the taxon were classified according to previous classifications (Özdemir and Senel, 1999, 2001). In these observations, it was found out that glandular and aglandular hairs differ in variety and density according to the kinds of taxa and related organs. Investigated taxa of Salvia have various glandular and aglandular hairs on the stem, leaf, petiole and flower. The glandular hairs are more variable and greater in number on flowers than on the other parts of the plants. There were all types of capitate and

Table 1 - The investigated samples and their voucher specimens

\begin{tabular}{|c|c|c|c|c|}
\hline Code & Taxon & Herbarium $\mathrm{N}^{\mathrm{O}}$ & Locality & Date \\
\hline \multirow{2}{*}{ A } & \multirow{2}{*}{ Salvia viridis } & Özdemir 028 & Samsun: Çakallı $900 \mathrm{~m}$ & 22.05 .2015 \\
\hline & & Akyol 038 & Manisa:Gölmarmara $800 \mathrm{~m}$ & 30.04 .2014 \\
\hline \multirow{2}{*}{$\mathrm{B}$} & \multirow{2}{*}{ Salvia verticillata subsp. amasiaca } & Özdemir 029 & Samsun: Ladik $200 \mathrm{~m}$ & 24.06 .2014 \\
\hline & & Özdemir 040 & İzmir: Bornova $200 \mathrm{~m}$ & 29.06 .2014 \\
\hline $\mathrm{C}$ & Salvia virgata & Özdemir 030 & Samsun: Kavak $900 \mathrm{~m}$ & 24.06 .2015 \\
\hline $\mathrm{D}$ & Phlomis pungens var. pungens & Özdemir 039 & Manisa: Muradiye $900 \mathrm{~m}$ & 29.06 .2014 \\
\hline $\mathrm{E}$ & Phlomis pungens var. hispida & Özdemir 032 & Samsun: Çakalli $900 \mathrm{~m}$ & 24.06 .2015 \\
\hline $\mathrm{F}$ & Stachys cretica subsp. anatolica & Özdemir 034 & Samsun: Çakallı $900 \mathrm{~m}$ & 24.06 .2015 \\
\hline $\mathrm{G}$ & Stachys cretica subsp. smyrnaea & Özdemir 042 & İzmir: Bornova $200 \mathrm{~m}$ & 20.06 .2014 \\
\hline $\mathrm{H}$ & Teucrium scordium subsp. scordioides & Özdemir 044 & Trabzon: Zeytinlik $300 \mathrm{~m}$ & 28.09 .2014 \\
\hline
\end{tabular}


peltate hairs in the studied Salvia taxa. The first type of capitate hairs, which has two head cells, has been observed in $S$. virgata but not in S. verticillata subsp. amasiaca and $S$. viridis. These capitate glandular hairs have a great number of base cells and stalk cells in the studied Salvia taxa. In addition, stalk cells are not present in some of them. The second type of peltate hair has been observed in all of the studied Salvia taxa. There are 1, 2, 4 central cells and peripheral cells in different numbers in these peltate hairs. Different numbers of tall and simpler aglandular hairs were seen in these Salvia taxa (Figure 1, 2, 3). This result is supported in the literature. According to previous research studies, Salvia taxa have more glandular hairs than the other genera of the same family (Werker et al., 1985; Kesercioglu and Nakipoglu, 1992). It was observed that the examined taxa of Salvia have high density of peltate hairs on the leaves and flowers but not on other parts. Similar results were found in the literatüre (Özkan and Soy, 2007; Özkan, 2008). It can be thought that secretion in peltate hair gives the characteristic smell rather than in capitate hair.

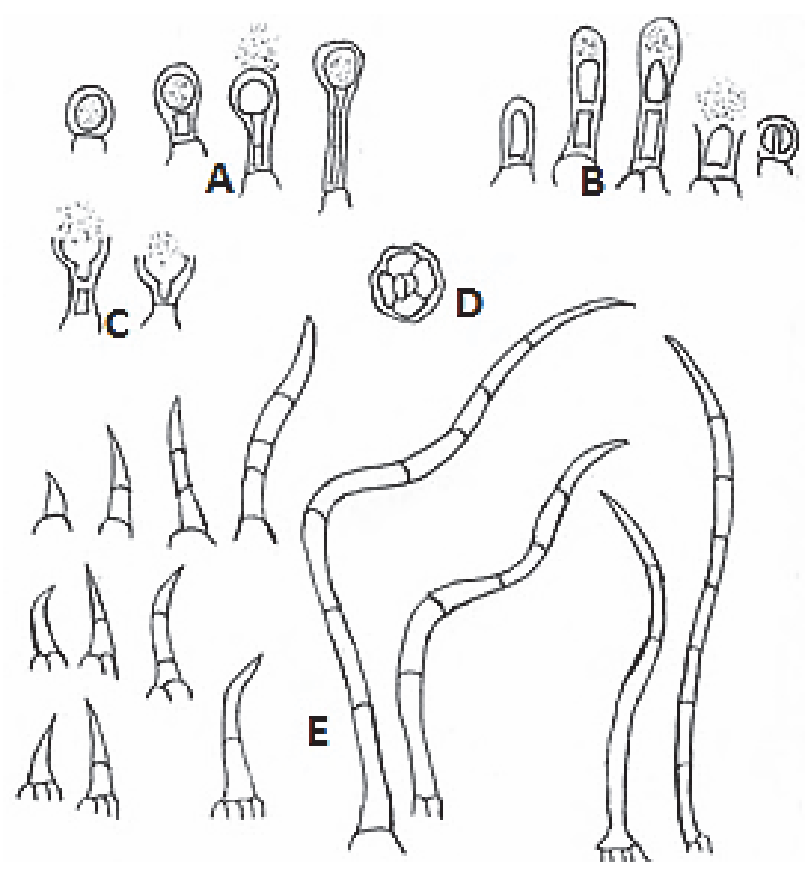

A-C- Capitate D- Peltate Glandular hairs (A: type I B: type II C: type III), E- Aglandular hairs.
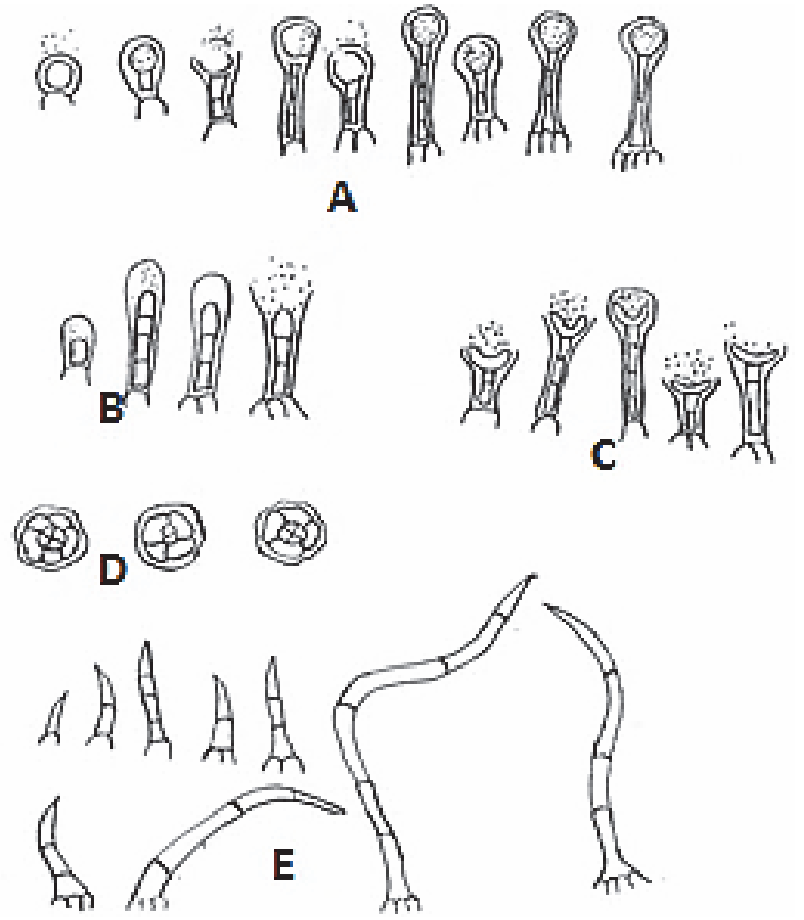

A-C- Capitate D- Peltate Glandular hairs (A: type I B: type II C: type III), E- Aglandular hairs.

Figure 1 - Salvia viridis.

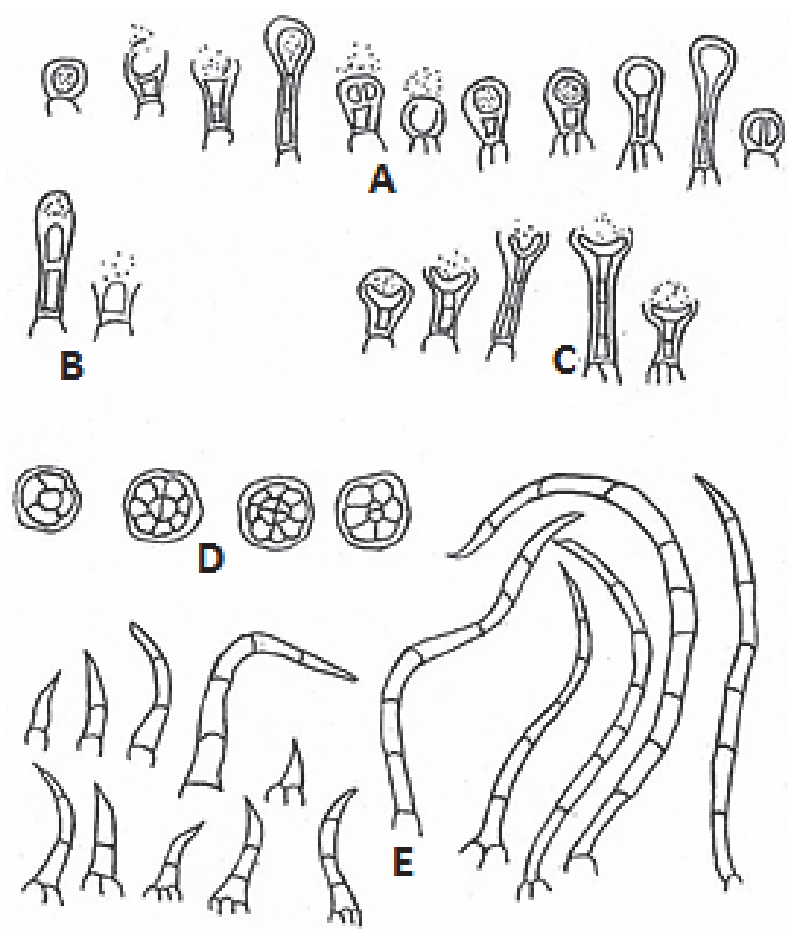

A-C- Capitate (A: type I B: type II C: type III), D- Peltate Glandular hairs, E- Aglandular hairs.

Figure 2 - S. verticillata subsp. amasiaca.

Figure 3 - Salvia virgata. 
While $P$. pungens var. hispida has type III capitate hair, $P$. pungens var. pungens does not have it. On the other hand, type III capitate hair was seen in Stachys cretica subsp. anatolica but not in Stachys cretica subsp. smyrnaea is considered to be a character to distinguish the subspecies from each other. According to the statistical analysis, significance of the differences between the investigated taxa was evaluated by analysis of variance (Regression Analysis) and Pearson correlation. And the statistical analysis of the results are shown in Tables 2 and 3.

The differences, which were evaluated with Pearson correlation, between investigated taxa based on number of hairs, were shown as A-B, A-C, A-D, A-E, B-C, B-D, C-D, D-E, F-G, F-H, G-H in Table 2, and they are significant at levels of 0.01 and 0.05 .

The differences evaluated with Regression Analysis are shown as A-B, A-D, A-E, B-C, C-D, D-E, F-G, F-H, G-H in Table 3, and they are significant at levels of 0.01 and 0.05.

Table 2 - Correlation (Pearson correlation) between investigated taxa based on numbers hairs

\begin{tabular}{|l|l|l|l|l|l|l|l|}
\hline & $\mathrm{A}$ & $\mathrm{B}$ & $\mathrm{C}$ & $\mathrm{D}$ & $\mathrm{E}$ & $\mathrm{F}$ & $\mathrm{G}$ \\
\hline \multirow{2}{*}{$\mathrm{B}$} & 0.998 & & & & & & \\
\hline & $0.001^{* *}$ & & & & & & \\
\hline \multirow{2}{*}{$\mathrm{C}$} & 0.975 & 0.999 & & & & & \\
\hline & $0.050^{*}$ & $0.001^{* *}$ & & & & & \\
\hline \multirow{2}{*}{$\mathrm{D}$} & 0.976 & 0.873 & 0.701 & & & & \\
\hline & $0.051^{*}$ & $0.050^{*}$ & $0.036^{*}$ & & & & \\
\hline \multirow{2}{*}{$\mathrm{E}$} & 0.667 & 0.848 & 0.722 & 0.827 & & & \\
\hline & $0.050^{*}$ & 0.070 & 0.105 & $0.042^{*}$ & & & \\
\hline \multirow{2}{*}{$\mathrm{F}$} & 0.293 & 0.352 & 0.327 & 0.310 & 0.231 & & \\
\hline & 0.573 & 0.494 & 0.527 & 0.551 & 0.659 & & \\
\hline \multirow{2}{*}{$\mathrm{G}$} & 0.284 & 0.341 & 0.317 & 0.284 & 0.229 & 0.728 & \\
\hline & 0.585 & 0.509 & 0.540 & 0.586 & 0.662 & $0.026^{*}$ & \\
\hline \multirow{2}{*}{$\mathrm{H}$} & 0.267 & 0.320 & 0.298 & 0.250 & 0.229 & 0.958 & 0.991 \\
\hline & 0.610 & 0.536 & 0.566 & 0.633 & 0.663 & $0.003 * *$ & $0.001^{* *}$ \\
\hline
\end{tabular}

* Significant at the level of 0.05 . ** Significant at the level of 0.01. A-G: Taxon Codes.

The results of the statistical analysis are shown in Tables II and III. It was found that there were important correlations between S. viridis, S. verticillata subsp. amasiaca and S. virgata, which belong to the same genera. On the other hand, there are important differences between Phlomis pungens var. pungens P. pungens var. hispida and Stachys cretica subsp. anatolica - S. cretica subsp. smyrnaea which are close taxa as systematically and belong to the same genera. It is mentioned that there are close relationships between the investigated taxa (Davis, 1982). Also, according to the statistical results, there is a considerable relation between the two taxa, at the level of $\mathrm{P}<.01$ and .05 (Table 2, III).

Consequently, these characters about hairs will help to distinguish the taxa and genera from each other. In the literature, some
Table 3 - Correlation (Regression Analysis) between investigated taxa based on number hair

\begin{tabular}{|c|c|c|c|c|}
\hline Taxon & MS & F-value & Probility & Significicance \\
\hline A-B & 150.21 & 954.2 & 0.001 & $* *$ \\
\hline A-D & 99.860 & 99.57 & 0.043 & $*$ \\
\hline A-E & 83.711 & 87.22 & 0.050 & $* *$ \\
\hline A-F & 12.250 & 5.700 & 0.053 & NS \\
\hline A-G & 12.170 & 9.640 & 0.058 & NS \\
\hline B-C & 912.60 & 28.32 & 0.010 & $* *$ \\
\hline B-D & 71.670 & 4.530 & 0.092 & NS \\
\hline B-G & 19.170 & 14.78 & 0.521 & NS \\
\hline C-D & 519.92 & 58.04 & 0.005 & $* *$ \\
\hline D-E & 158.31 & 134.5 & 0.042 & $*$ \\
\hline F-G & 879.20 & 96.39 & 0.027 & $*$ \\
\hline F-H & 89.570 & 48.18 & 0.003 & $* *$ \\
\hline G-H & 199.57 & 48.18 & 0.006 & $* *$ \\
\hline
\end{tabular}

MS: mean square. ${ }^{*} \mathrm{p}<.05 .{ }^{* *} \mathrm{p}<.01$. NS: not significant. A-H: taxon codes. 
researchers observed similar results to our findings in their studies (Dinç and Öztürk, 2008; Venkateshappa and Sreenath, 2013). In addition to these anatomical features, the differences in hair morphology are ancillary observations that serve to generally increase anatomical knowledge of the family. They will also be useful for future investigators of these genera of Lamiaceae (Figures 4 - 8, Table 4).
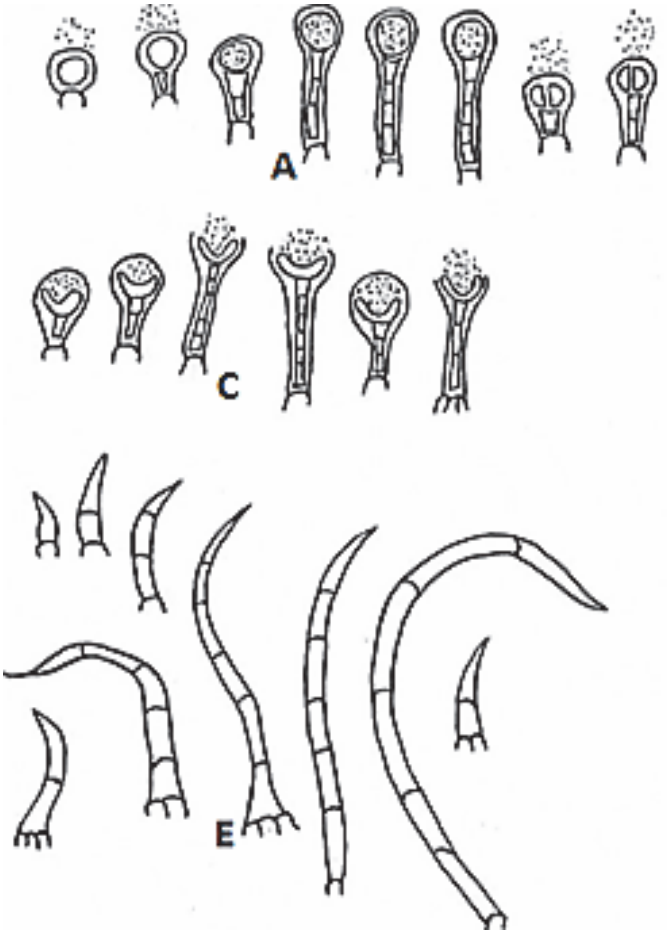

A-C- Capitate (A: type I B: type II C: type III), D- Peltate Glandular hairs, E- Aglandular hairs.
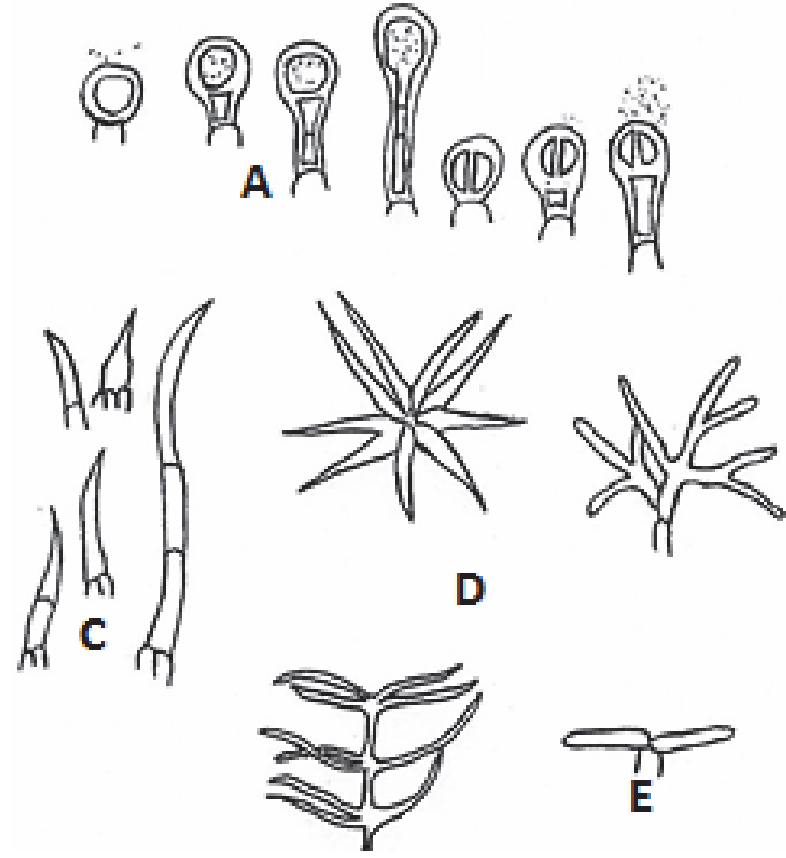

A-B Capitate (A: type I B: type III), C-Simple hairs, D-Branched hairs, E-Shield hair.

Figure 5 - Phlomis pungens var. pungens.

Figure 4 - Teucrium scordium subsp. scordioides.
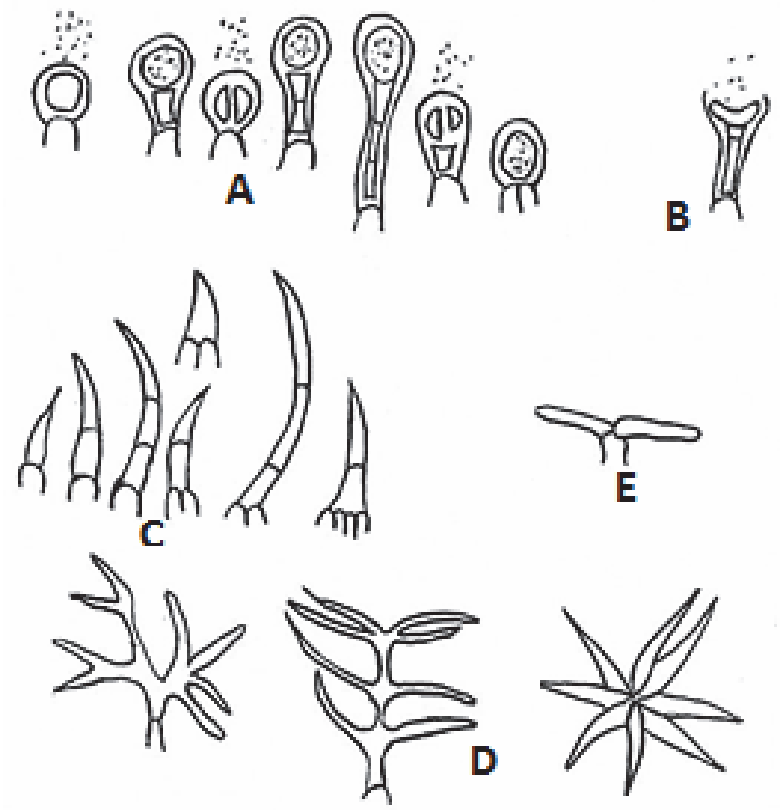

A-B Capitate (A: type I B: type III), C-Simple hairs, D-Branched hairs, E-Shield hair.

Figure 6 - Phlomis pungens var. hispida. 

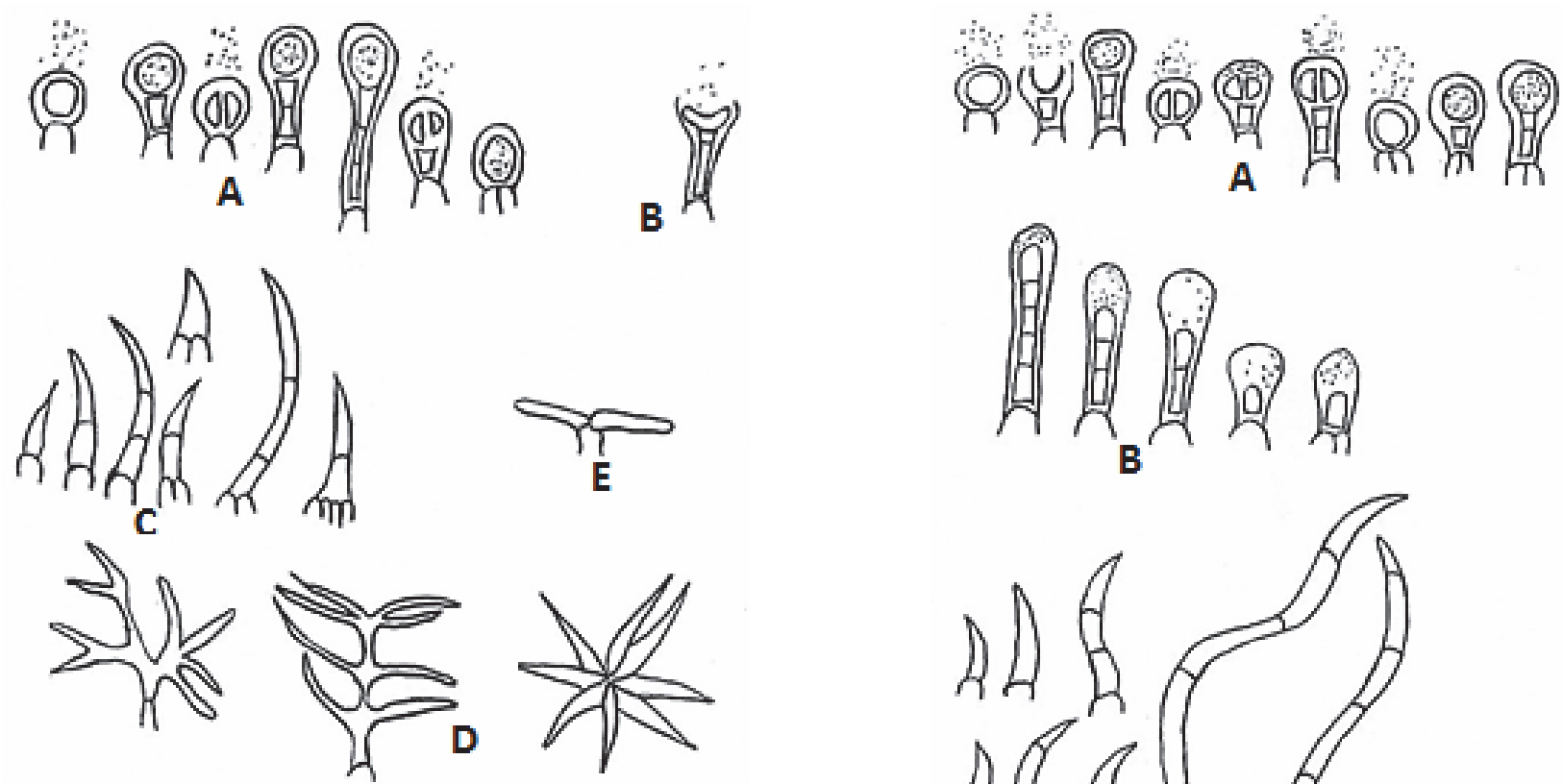

A-B-C- Capitate glandular (A: type I B: type II C: type III), DAglandular hairs.

Figure 7 - Stachys cretica subsp. anatolica.

A-B-C- Capitate glandular (A: type I B: type II C: type III), D-Aglandular hairs.

Figure 8 - S. cretica subsp. smyrnaea.

Table 4 - The distrubitionof hairs of investigated taxa

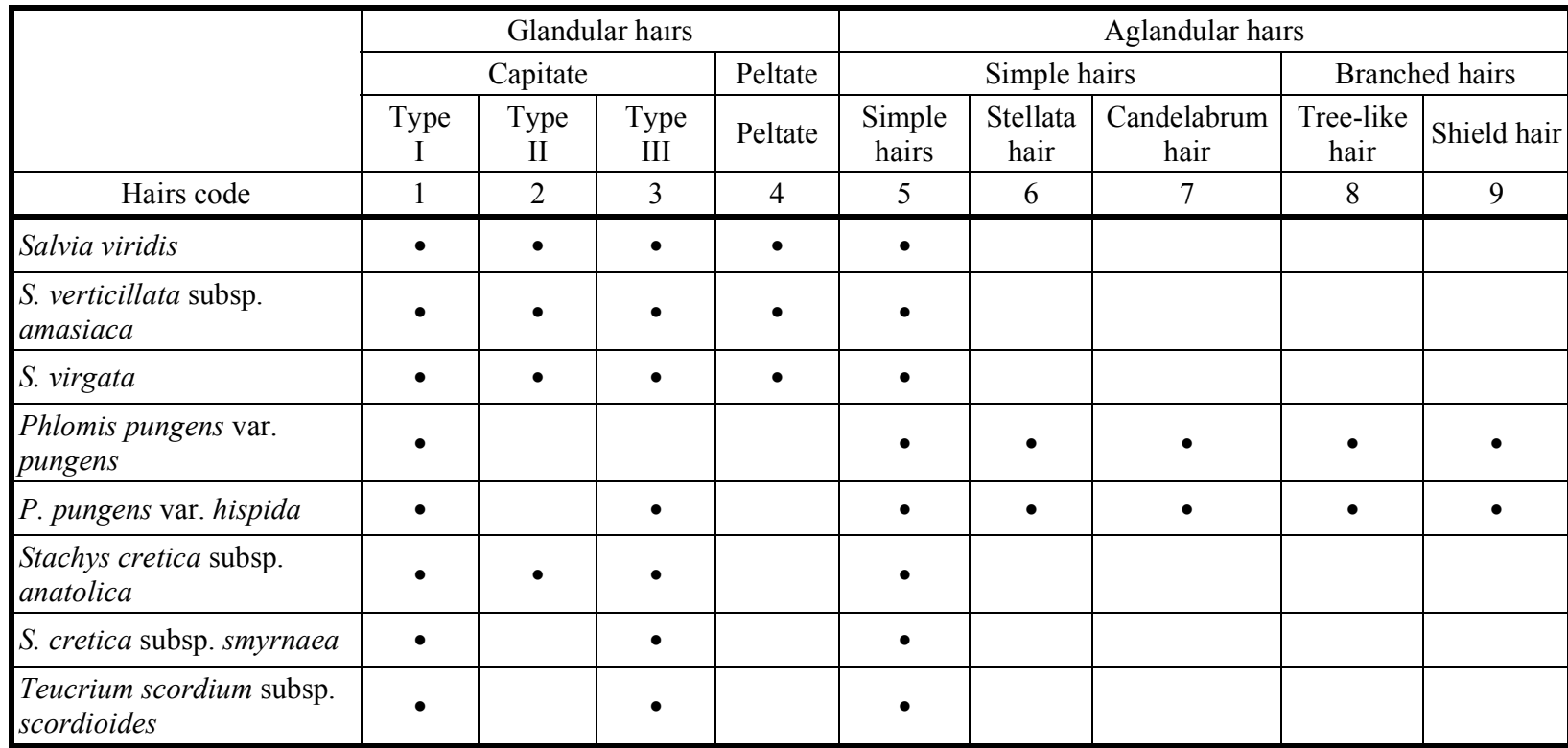

- Present.

\section{REFERENCES}

Baran P., Özdemir C. Morphological, anatomical and cytological studies on endemic Lamium pisidicum. Pak J Bot. 2013;45:7385.

Baran P., Özdemir C. Morphological, anatomical and cytological investigation on Endemic Lamium moschatum var. rhodium (Gand.) R. Mill. Biologia. 2011;66:439-47. 
Baran P., Aktas K., Özdemir C. Structural investigation of the glandular trichomes of endemic Salvia smyrnea L. South Afr J Bot. 2010;76:572-8.

Baran P., Özdemir C. The morphological and anatomical properties of Lamium lycium (Lamiaceae), endemic to Turkey. Nordic $\mathbf{J}$ Bot. 2009;27:1-9.

Baran P., Özdemir C. The morphological and anatomical characters of Salvia napifolia Jacq. in Turkey. Banglad J Bot. 2006;35:77-84.

Baser K.H.C. Essential oils of Anatolian Lamiaceae: A profile. Acta Hortic. 1993;333:217-38.

Baytop T. Bitkisel Drogların Anatomik Yap1s1. Istanbul: Istanbul Üniversity Yay, 1981.

Baytop T. Türkiye’de Bitkiler ile Tedavi. (Geçmiste ve Bugün). Istanbul: Istanbul Üniversity Yay, 1984.

Bendiksby M. et al. An updated phylogeny and classification of Lamiaceae subfamily Lamioideae. Taxon. 2011;60:471-84.

Davis P.H. Flora of Turkey and the East Aegean Islands. Edinburgh: Edinburgh University Press, 1982. v.7.

Dinç M., Öztürk M. Comparative morphological, anatomical, and palynological studies on the genus Stachys L. sect. Ambleia Bentham (Lamiaceae) species in Turkey. Turkish J Bot. 2008;32:113-21.

Duarte M.R., Lopes J.F. Stem and leaf anatomy of Plectranthus neochilus Schltr., Lamiaceae. Braz J Pharm. 2007;17:549-56.

Koca F. Micromeria congesta Boiss. et. Hausskn ex. Boiss üzerinde morfolojik ve anatomik arapstırmalar. Turkish J Bot. 1996;20:21-30.

Kesercioglu T., Nakipoglu M. Investigations on some Salvia L. species collected from Turkey, Arom Spice Crops. 1992;2:32544.

Nakipoglu M. Bazi adaçayi (Salvia L.) türleri ve türlerin ekonomik önemi, Dokuz Eylül Üniversitesi Egitim Bilimleri Dergisi, v.6, p. 45-58. 1993

Özdemir C., Senel G. The morphological anatomical and karyological properties of Salvia sclarea L. Turkish J Bot. 1999;23:718.

Özdemir C., Senel G. The morphological anatomical and karyological properties of Salvia forskahlei L. J Econ Taxonomic Bot. 2001:19:297-313.

Özdemir C. Morphological and anatomical studies on two varieties of Phlomis pungens Wild. (Lamiaceae). Sci Res Essays. 2011;6:5168-78.

Özkan M., Soy E. Morphology, anatomy, hair and karyotype structure of Salvia blepharochlaena Hedge \& Hub-Mor. (Lamiaceae), endemic to Turkey. Pakistan J Biol Sci. 2007;10:893-8.

Özkan M. Glandular and eglandular hairs of Salvia recognita Fisch. \& Mey. (Lamiaceae) in Turkey. Bangladesh J Bot. 2008;37:93-5.

Özkan M., Özdemir C., Soy E. Morphological, anatomical and karyological properties of Salvia cadmica Boiss. (Lamiaceae) endemic to Anatolia. Flora Mediter. 2008;18:361-71.

Özkan M. et al. Nutlet morphology and its taxonomic utility in Salvia (Lamiaceae: Mentheae) from Turkey. Acta Bot Croatica. 2009:68:105-15.

Werker E., Rav1d U., Put1evsky E. Structure of glandular hairs and ýdentification of the main components of their secreted material in some species of the Lamiaceae, Israel J Bot. 1985;34:31-45.

Venkateshappa S.M., Sreenath K.P. Some species of lamiaceae- comparative anatomical studies. Indo Am J Pharm Res. 2013;3:9249-54. 